\title{
Tea Extract Prevents Arsenic-mediated DNA Damage and Death of Murine Thymocytes in vitro
}

\section{Masuma Akter ${ }^{1, \eta}$, Nafisa Nawal Islam ${ }^{1, \pi}$, Ahmed Faisal Sumit ${ }^{1}$, Nazmul Ahsan ${ }^{1}$, Shahanoor Hossain ${ }^{1}$, Mamun Ahmed ${ }^{2}$ and Anwarul Azim Akhand ${ }^{1}$}

\author{
${ }^{1}$ Department of Genetic Engineering and Biotechnology, University of Dhaka, Dhaka-1000, Bangladesh \\ ${ }^{2}$ Department of Biochemistry and Molecular Biology, University of Dhaka, Dhaka-1000, Bangladesh
}

Received: April 27, 2015; Accepted: May 13, 2015; Published (web): June 15, 2015

\begin{abstract}
Groundwater contamination by arsenic has created a major health hazard in Bangladesh by affecting millions of people. In this study, we report cytotoxic effects of arsenic in primary culture of murine thymocytes and the counteractive actions of tea extract to reduce this cytotoxic effects. When murine thymocytes were incubated for shorter period $(1 \mathrm{~h})$ with higher concentrations $(50$ and $100 \mu \mathrm{M})$ of sodium arsenite $\left(\mathrm{NaAsO}_{2}\right)$, cell viability was decreased to $79.06 \pm 0.52 \%$ and $62.53 \pm 0.23 \%$, respectively. In case of longer incubation (16 hrs) with a wide range of $\mathrm{NaAsO}_{2}$ concentration (1-100 $\mu \mathrm{M}$ ), cell viability was reduced from $89.30 \pm 0.84 \%$ to $79.0 \pm 0.52 \%$ by $1 \mu \mathrm{M}$ $\mathrm{NaAsO}_{2}$, and this reduction was continued with increasing concentration reaching to $29.60 \pm 0.72 \%$ by $100 \mu \mathrm{M}$. Tea is known to possess antioxidant property and we found that this tea extract reduced $\mathrm{NaAsO}_{2}$-mediated death of the cells in culture. After $16 \mathrm{~h}$ of incubation, the chromosomal DNA of $5 \mu \mathrm{M} \mathrm{NaAsO}{ }_{2}$-exposed cells was found degraded suggesting apoptotic death of the cells. Interestingly, this degradation of chromosomal DNA was blocked by tea extract. All of these results together suggest a future therapeutic application of tea extract to reduce or block arsenic toxicity.
\end{abstract}

Key words: Sodium arsenite, tea extract, cytotoxicity, thymocyte

\section{INTRODUCTION}

Arsenic is a notorious metalloid occurring naturally in the environment as an element of earth's crust. A huge population of Bangladesh and other countries is exposed to arsenic mainly through drinking contaminated ground water. ${ }^{1,2}$ As a consequence, millions of people are affected and many of them are suffering from skin cancers, neurodegenerative/cardiovascular disorder, liver/ kidney damage, diabetes, immunotoxicity, etc. ${ }^{3-7}$ In the last few years, there has been increasing evidence of a correlation between arsenic exposure and generation of reactive oxygen species (ROS). ${ }^{8-10}$ The generated ROS are known to cause an imbalance of cellular antioxidant defense mechanism leading to adverse effects. ${ }^{8}$ In addition, arsenic is capable of

\footnotetext{
"Equally contributed

Correspondence to: Anwarul Azim Akhand

Tel. No: (02)9661920 ext. 7818

Fax: 880-2-9667222

E-mail: akhand66@yahoo.com
}

Dhaka Univ. J. Pharm. Sci. 14(1): 79-85, 2015 (June) binding and cross-linking cellular proteins thereby activating multiple cellular signaling pathways that may also result in cellular dysfunction. ${ }^{11,12}$

As arsenic toxicity is known to be mediated in great part through the generation of ROS, antioxidants therefore are thought to be capable of acting against arsenic-induced toxicity. Consequently, antioxidant properties of various plant sources have drawn the attention of many researchers for exploring their possible ameliorating effect against arsenic. Turmeric, widely used as a spice in Asian nations, has been shown to reduce arsenicmediated adverse effects in mice by virtue of its antioxidant potentials. ${ }^{13}$ In addition, fruit extract of Emblica officinalis protected arsenic-induced oxidative damage and apoptosis in splenocytes of mice. ${ }^{14}$ Moreover, we have recently shown the protective effects of Phyllanthus emblica leaf extract (PLE) and water hyacinth root powder on arsenicmediated toxicity in experimental mice. ${ }^{15,16}$ 
Tea has been traditionally used as a drink worldwide, which is known to possess various health benefits. Both green and black tea contain different forms of catechins and their derivatives making both types of tea capable of working as potential antioxidants. ${ }^{17}$ Multiple biological effects of tea have so far been described, among them are antiinflammatory, anti-allergic, anti-aging, antimutagenic, anti-diabetic, and antimicrobial activities. ${ }^{18-20}$ To find some way out to remediate arsenic toxicity is highly important for an ultimate target of developing effective therapeutics. In this study, we investigated the ameliorating effects of Bangladeshi black tea (known as flowery broken orange pekoe) on arsenic-mediated cytotoxicity in murine thymocytes in vitro.

\section{MATERIALS AND METHODS}

Culture of murine thymocytes. Swiss albino mice of 6-8 weeks age were purchased from Animal division of International Center for Diarrhoeal Disease Research, Bangladesh (ICDDR, B). Mice were sacrificed by cervical dislocation and the ventral side was opened surgically to collect thymus. Single cell suspensions of thymocytes were prepared in RPMI-1640 medium (Gibco BRL, CA). Cell suspensions were incubated in the presence or absence of $\mathrm{NaAsO}_{2}$ (Merck, Germany) dissolved in phosphate buffered saline (PBS) at $37{ }^{\circ} \mathrm{C}$ before further analysis.

Preparation of black tea extract. Black tea was purchased from the local market as granular powder and $50 \mathrm{~g}$ of this tea powder was soaked in $200 \mathrm{ml}$ distilled water in a flask followed by boiling for 30 min. The extract was then filtered using Whatman filter paper (no. 11) to collect filtrate and to remove residual particulates. The tea filtrates were then lyophilized using freeze-dryer to get the dried extract. Yield of the extract was $\sim 12 \%$. Dried extract was stored at $4{ }^{\circ} \mathrm{C}$ and was dissolved in phosphate buffer saline (PBS) before use.

Cell viability assay. Cell viability was determined with the trypan blue dye exclusion assay.
Briefly, thymocytes were suspended in $500 \mu$ RPMI1640 media and plated on 24-well plates $\left(5 \times 10^{5}\right.$ cells/well) in the presence or absence of $\mathrm{NaAsO}_{2}$ followed by incubation at $37^{\circ} \mathrm{C}$ for desired period of time. Tea extracts $(200 \mu \mathrm{g} / \mathrm{ml})$ were added in some groups of cells when needed. At the end of incubation, cells were collected, washed and resuspended in PBS. For staining of the cells, equal volumes of cell suspension and trypan blue $(0.4 \%)$ solution were mixed. Both viable and dead cells were counted using a hemocytometer under an inverted microscope (Olympus, Tokyo, Japan). Dead cells turned into blue as the dye entered into them through damaged membrane.

Analysis of DNA damage by electrophoresis. Cellular DNA damage was analyzed using the method reported previously. ${ }^{21}$ Briefly, cells were lysed in $100 \mu \mathrm{l}$ of hypotonic lysing buffer (50 mM Tris-HCl, $0.5 \%$ SDS, $10 \mathrm{mM}$ EDTA) followed by the addition of $2 \mu \mathrm{l}$ of proteinase $\mathrm{K}(20 \mathrm{mg} / \mathrm{ml})$ and $6 \mu \mathrm{l}$ of RNase $(10 \mathrm{mg} / \mathrm{ml})$. The resultant mixture was incubated at $55^{\circ} \mathrm{C}$ for $1 \mathrm{hr}$. Each sample $(10 \mu \mathrm{l})$ was mixed with $3 \mu \mathrm{l}$ of $0.25 \%(\mathrm{w} / \mathrm{v})$ bromophenol blue and $40 \%(\mathrm{w} / \mathrm{v})$ sucrose and was run on $1.0 \%$ agarose gel with $0.1 \mu \mathrm{g} / \mathrm{ml}$ ethidium bromide. DNA bands were visualized under UV light.

\section{RESULTS AND DISCUSSION}

$\mathrm{NaAsO}_{2}$ reduced viability of thymocytes in vitro. Murine thymocytes were exposed without or with $\mathrm{NaAsO}_{2}$ (50 and $100 \mu \mathrm{M}$ ) for $1 \mathrm{~h}$ and the viable cells were counted. In untreated control, $98.4 \pm$ $0.58 \%$ of the cells remained viable, however; cell viability was reduced to $79.06 \pm 0.52 \%$ and $62.53 \pm$ $0.10 \%$ by treating the cells with 50 and $100 \mu \mathrm{M}$ of $\mathrm{NaAsO}_{2}$, respectively (Figure 1A). When cells were incubated with a wide range of $\mathrm{NaAsO}_{2}$ concentration (1-100 $\mu \mathrm{M})$ for longer period (16 h), cell viability was reduced in a concentrationdependent manner (Figure 1B). Viable cells were reduced to $79.00 \pm 0.52 \%, 70.10 \pm 0.50 \%, 62.9 \pm$ $0.19 \%, 48.2 \pm 0.14 \%$ and $29.60 \pm 1.5 \%$ by $1,5,10$, 50 and $100 \mu \mathrm{M} \mathrm{NaAsO}$, respectively. Incubation of the control cells for prolonged $16 \mathrm{~h}$ even caused 
reduction of cell viability to $89.73 \pm 0.84 \%$ (Figure 1B) compared with that of the cells incubated for $1 \mathrm{~h}$ only (Figure 1A).

Tea extract partially prevented $\mathrm{NaAsO}_{2}$ mediated cell death. We next examined whether tea extract could prevent $\mathrm{NaAsO}_{2}$-mediated reduction of cell viability. It was found that tea extract prevented $\mathrm{NaAsO}_{2}$-mediated cell death partially when the extract was added to the culture prior to $\mathrm{NaAsO}_{2}$

A

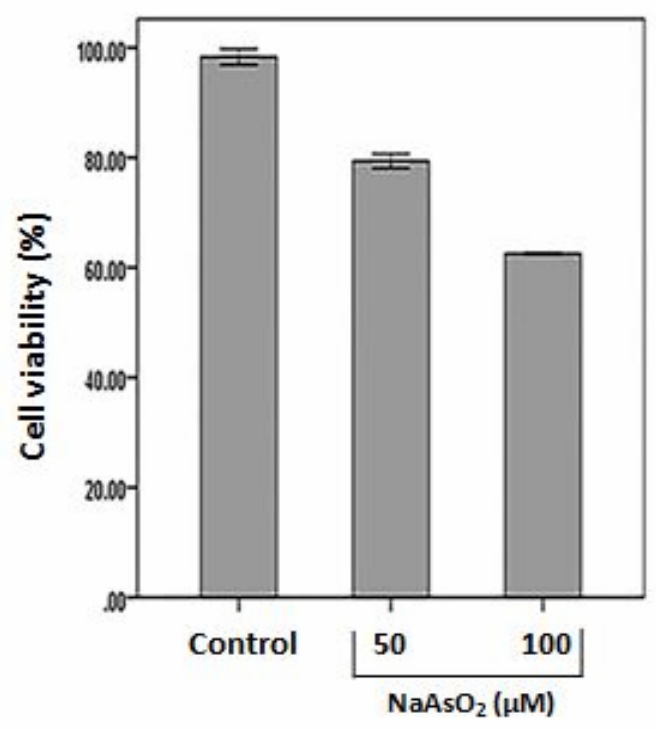

addition (Figure 2). This result indicated that tea extract might play some role to prevent death of cells associated with $\mathrm{NaAsO}_{2}$ exposure. The effect of tea extract in promoting cell viability, however, was less evident on cells exposed to higher concentrations of $\mathrm{NaAsO}_{2}(50 \mu \mathrm{M}-100 \mu \mathrm{M})$. Tea extract alone did not reduce rather slightly increased the viability of the cells compared to the control, suggesting no visible adverse effects of the extract alone on cell viability.

B

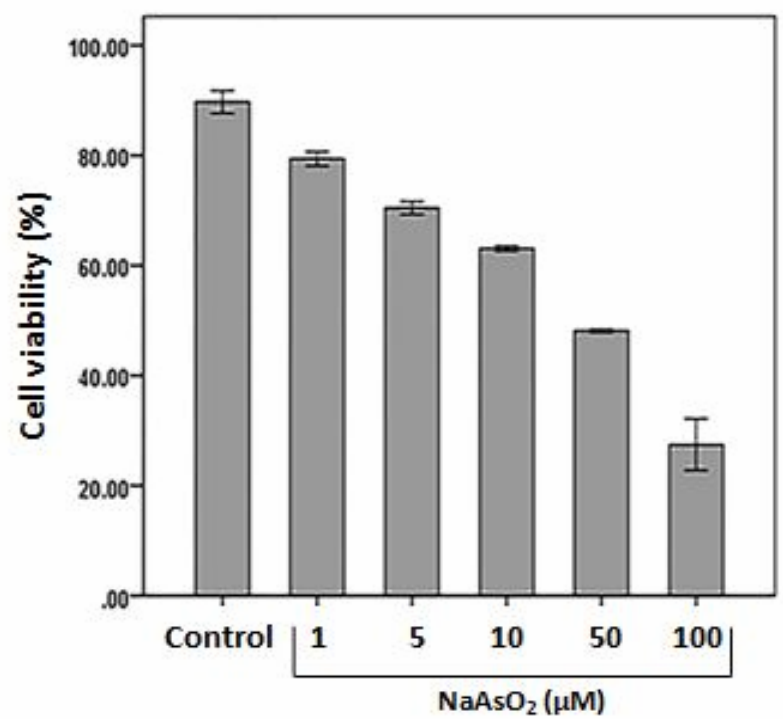

Figure 1. $\mathrm{NaAsO}_{2}$ reduced viability of thymocytes in culture. Thymocytes were treated without or with $50-100 \mu \mathrm{M}$ of $\mathrm{NaAsO}_{2}$ for $1 \mathrm{~h}(\mathrm{~A})$ and without or with 1-100 $\mu \mathrm{M}$ of $\mathrm{NaAsO}_{2}$ for $16 \mathrm{~h}$ (B). Viable cells were counted using trypan blue dye exclusion assay as described in the materials and methods. Each column represents the mean \pm SD of triplicate assays.

$\mathrm{NaAsO}_{2}$-mediated cell death was accompanied by chromosomal DNA degradation. Cell death induced by lower concentrations of $\mathrm{NaAsO}_{2}$ in this study might be due to apoptosis associated with degradation of chromosomal DNA. We, therefore, examined whether the cells exposed to $\mathrm{NaAsO}_{2}$ might accompany degradation of DNA or not. The intensity of the band for chromosomal DNA of $5 \mu \mathrm{M}$ $\mathrm{NaAsO}_{2}$-treated cells was decreased compared with that of the control cells, indicating degradation of chromosomal DNA (Figure 3). No clear band for the degraded DNA fragments, however, was detected at the lower portion of the gel probably due to some limitations of the method used. It was also observed that lower or higher than $5 \mu \mathrm{M}$ of $\mathrm{NaAsO}_{2}$ did not induce degradation of DNA.

Tea extract prevented $\mathrm{NaAsO}_{2}$-mediated DNA damage. Finally, we examined whether the tea extract could prevent arsenic-mediated induction of DNA damage. We interestingly observed that the tea extract, when added to the cells prior to $\mathrm{NaAsO}_{2}$ addition, prevented cellular DNA damage (Figure 4). This result suggested that tea extract might play a role in blocking arsenic-mediated apoptosis in thymocytes. 


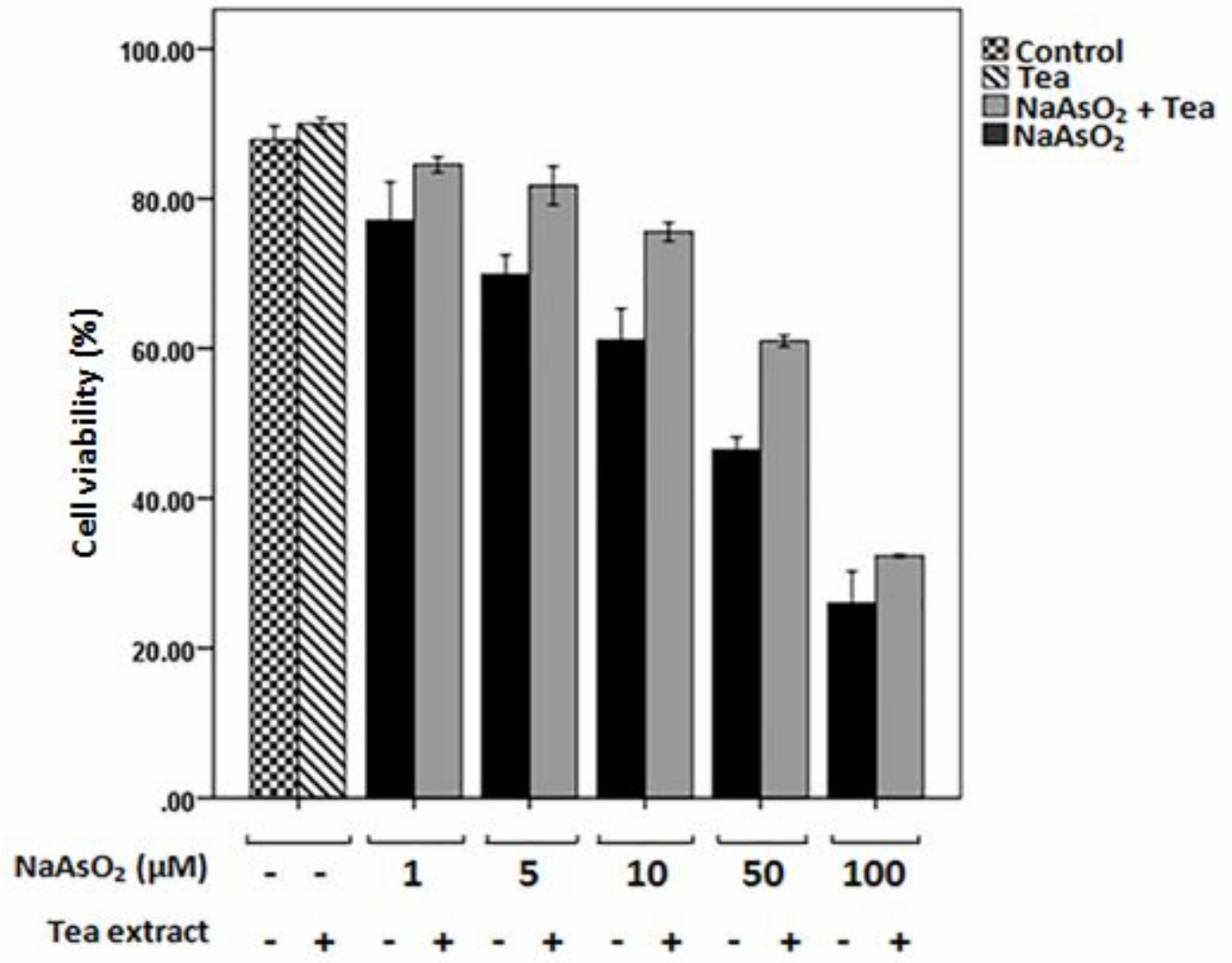

Figure 2. Tea extract partially prevented $\mathrm{NaAsO}_{2}$-mediated death of thymocytes. Thymocytes were incubated without or with 1-100 $\mu \mathrm{M}$ of $\mathrm{NaAsO}_{2}$ for $16 \mathrm{~h}$. Tea extract $(200 \mu \mathrm{g} / \mathrm{ml})$ was added prior to $\mathrm{NaAsO}_{2}$ addition as indicated. Viable cells were counted using trypan blue dye exclusion assay as described in the materials and methods. Each column represents the mean \pm SD of triplicate assays.

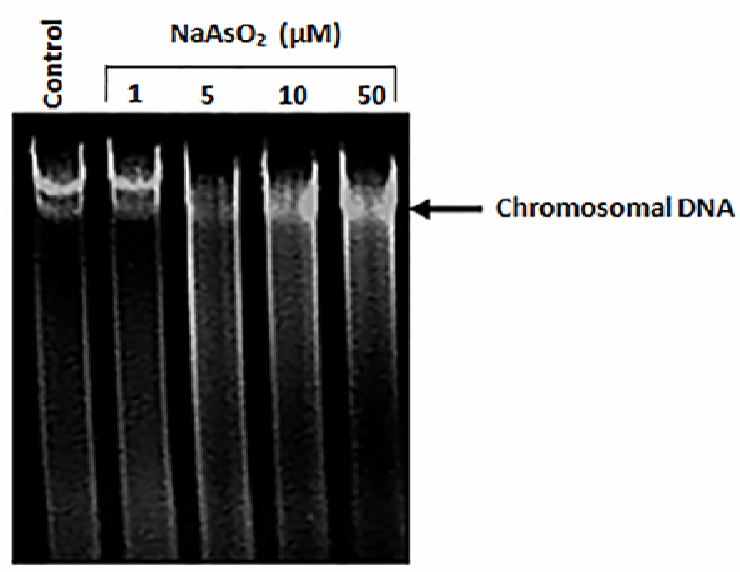

Figure 3. $\mathrm{NaAsO}_{2}$ induced DNA damage in thymocytes. Thymocytes were incubated with or without the indicated concentrations of $\mathrm{NaAsO}_{2}$ for $16 \mathrm{~h}$. These cells were lysed in hypotonic lysing buffer and DNAs were then analyzed by agarose gel electrophoresis.

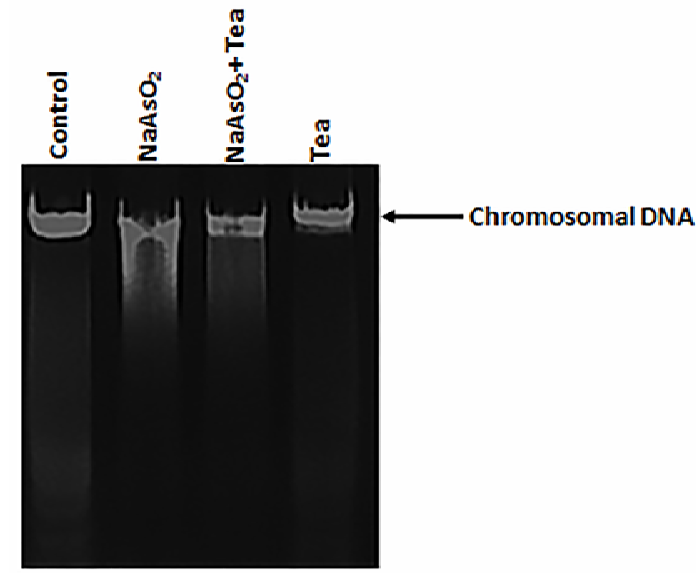

Figure 4. Tea extract blocked $\mathrm{NaAsO}_{2}$-mediated damage of DNA. Thymocytes were incubated for $16 \mathrm{~h}$ with or without $5 \mu \mathrm{M}$ $\mathrm{NaAsO}_{2}$. Tea extract $(200 \mu \mathrm{g} / \mathrm{ml})$ was added as indicated prior to addition of $\mathrm{NaAsO}_{2}$. These cells were lysed in hypotonic lysing buffer and DNAs were then analyzed by agarose gel electrophoresis.

Arsenic exposure to human and animal or to culture cells in vitro impairs various biochemical activities resulting in adverse effects. ${ }^{5,13,15,16,22,23}$ In 
the present study, the cytotoxic effects of $\mathrm{NaAsO}_{2}$ has been shown in culture of murine thymocytes as evident from the reduction in cell viability. Our results also complied with previous reports that have demonstrated arsenic-mediated induction of cell death in primary culture of murine thymocytes, splenocytes, hepatocytes or culture of leukemia cell lines. ${ }^{11,14,24-26}$

To find out a cost-effective and easily available means to counteract the cytotoxic effect of this poisonous compound would indeed be very beneficial. Accordingly, using agents with potential antioxidant properties could be one of the main approaches to ameliorate arsenic-induced cytotoxicity. Tea is considered, nowadays, a good source of dietary antioxidants endowed with biological and pharmacological activities for providing potential benefits to human health. ${ }^{27,28}$ The current study demonstrated that tea extract reduced death or promoted viability of the cells when the extract was added together with $\mathrm{NaAsO}_{2}$. The effect of tea extract in promoting cell viability, however, was less evident on cells exposed to higher concentrations of $\mathrm{NaAsO}_{2} \quad(50-100 \mu M)$. These higher concentrations might induce necrotic death of cells shortly after addition in culture through damage of cellular membrane. As the membrane integrity was lost by the effect of higher concentrations of $\mathrm{NaAsO}_{2}$, tea extract could not promote viability of those cells.

Arsenic at lower concentrations is known to induce apoptosis; therefore the death of the cells by lower concentrations of $\mathrm{NaAsO}_{2}$ in this study might also be due to apoptosis. We, indeed, observed that 5 $\mu \mathrm{M}$ of $\mathrm{NaAsO}_{2}$ induced degradation of chromosomal DNA in 16 hrs, supporting our view of apoptosis induction. This result was also in agreement with earlier reports of apoptotic death of cells associated with DNA fragmentation. ${ }^{11,24-26}$ Higher and lower than $5 \mu \mathrm{M}$ of $\mathrm{NaAsO}_{2}$ in this study, however, did not induce DNA fragmentation of exposed cells. This was probably because lower concentration $(1 \mu \mathrm{M})$ could not generate required amount of signal for apoptosis induction, whereas higher concentrations (10-50 $\mu \mathrm{M})$ induced toxic signals for necrotic cell death without DNA fragmentation. ${ }^{21}$ It can, therefore, be concluded from the present study that $\mathrm{NaAsO}_{2}$ induces cytotoxic death of cells via apoptosis and necrosis depending on the dose and duration of exposure.

Numerous studies have demonstrated that arsenic exposure induces oxidative stress through generation of free radicals/ROS thereby implicated in the induction of apoptosis. ${ }^{11,14,24,25}$ Such radicals react with intracellular signaling molecules to activate various pathways resulting in oxidative damage of DNA. What our results importantly have shown is that co-addition of tea extract attenuated $\mathrm{NaAsO}_{2}-$ mediated damage of DNA. The exact mechanism behind this effect is still unclear; however, the high antioxidant contents of tea ${ }^{17}$ might play roles in scavenging free radicals generated by $\mathrm{NaAsO}_{2} \cdot{ }^{29,30}$ Therefore, tea might have a beneficial role in lowering arsenic toxicity probably due to its radical scavenging property.

Bangladesh is facing what has already been described as perhaps the largest mass poisoning of a population in history. The results of this study are, therefore, encouraging because tea extract could be used to reduce or to prevent the toxic effect of arsenic. Further investigation is needed to identify the specific components of tea that are involved in mitigating the toxic effects of arsenic.

\section{ACKNOWLEDGEMENTS}

This work was supported in part by a grant from the University Grants Commission (UGC) of Bangladesh. We thank Dr. Sheikh Ariful Hoque, Centre for Advanced Research in Sciences (CARS), University of Dhaka, for providing cell culture facilities.

\section{REFERENCES}

1. Chowdhury, U.K., Biswas, B.K., Chowdhury, T.R., Samanta, G., Mondal, B.K., Basu, G.C., Chanda, C.R., Lodh, D., Saha, K.C., Mukherjee, S.K., Roy, S., Kabir, S., Quamruzzaman, Q. and Chakraborti, D. 2000. Groundwater arsenic contamination in Bangladesh and West Bengal, India. Environ. Health Perspect. 108, 393-397. 
2. Mclellan, F. 2002. Arsenic contamination affects millions in Bangladesh. Lancet 359, 1127.

3. Kitchin, K.T. and Kirk, T. 2001. Recent advances in arsenic carcinogenesis: Modes of action, animal model systems, and methylated arsenic metabolites. Toxicol. Appl. Pharmacol. 172, 249-261.

4. Chen, C.J., Wang, S.L., Chiou, J.M., Tseng, C.H., Chiou, H.Y., Hsueh, Y.M., Chen, S.Y., Wu, M.M. and Lai, M.S. 2007. Arsenic and diabetes and hypertension in human populations. Toxicol. Appl. Pharmacol. 222, 298-304.

5. Santra, A., Maiti, A., Das, S., Lahiri, S., Charkaborty, S.K. and Mazumder, D.N.G. 2000. Hepatic damage caused by chronic arsenic toxicity in experimental animals. J.Toxicol. Clin. Toxicol. 38, 395-405.

6. Sarker, R.S.J., Ahsan, N. and Akhand, A.A. 2012. Sodium arsenite induced systemic organ damage and changes in various blood parameters in mice. Dhaka Univ. J. Pharm. Sci. 11, 169-172.

7. Burchiel, S.W., Mitchell, L.A., Lauer, F.T., Sun, X., McDonald, J.D., Hudson, L.G. and Liu, K.J. 2009. Immunotoxicity and biodistribution analysis of arsenic trioxide in C57Bl/6 mice following a 2-week inhalation exposure. Toxicol. Appl. Pharmacol. 241, 253-259.

8. Pi, J., Yamauchi, H., Kumagai, Y., Sun, G., Yoshida, T. Aikawa, H., Hopenhayn-Rich, C. and Shimojo, N. 2002. Evidence for induction of oxidative stress caused by chronic exposures of Chinese residents to arsenic contained in drinking water. Environ. Health Perspect. 110, 331-336.

9. Li, B., Li, X., Zhu, B., Zhang, X., Wang, Y., Xu, Y., Wang, H., Hou, Y., Zheng, Q. and Sun, G. 2013. Sodium arsenite induced reactive oxygen species generation, nuclear factor (erythroid-2 related) factor 2 activation, heme oxygenase-1 expression, and glutathione elevation in Chang human hepatocytes. Environ. Toxicol. 28, 401-410.

10. Ruiz-Ramos, R., Lopez-Carrillo, L., Rios-Perez, A.D., De Vizcaya-Ruíz, A. and Cebrian, M.E. 2009. Sodium arsenite induces ROS generation, DNA oxidative damage, HO-1 and c-Myc proteins, NF-kappaB activation and cell proliferation in human breast cancer MCF-7 cells. Mutat. Res. 674, 109115.

11. Hossain, K., Akhand, A.A., Kato, M., Du, J., Takeda, K., Wu, J., Takeuchi, K., Liu, W., Suzuki, H. and Nakashima, I. 2000. Arsenite induces apoptosis of murine $T$ lymphocytes through membrane raft-linked signaling for activation of cJun amino-terminal kinase. J. Immunol. 165, 4290-4297.

12. Akhand, A.A., Du, J., Liu, W., Hossain, K., Miyata, T., Nagase, F., Kato, M., Suzuki, H. and Nakashima, I. 2004. Redox-linked cell surface-oriented signaling for T-cell death. Antioxid. Redox Signal. 4, 445-454.
13. Karim, M.R., Haque, A., Islam, K., Ali, N., Salam, K.A., Saud, Z.A., Hossain, E., Fazol, A., Akhand, A.A., Himeno, S. and Hossain, K. 2010. Protective effects of the dietary supplementation of turmeric (Curcuma longa L.) on sodium arsenite-induced biochemical perturbation in mice. Bangladesh Med. Res. Counc. Bull. 36, 82-88.

14. Singh, M.K., Yadav, S.S., Yadav, R.S., Singh, U.S., Shukla, Y., Pant, K.K. and Khattri, S. 2014. Efficacy of crude extract of Emblica officinalis (amla) in arsenic-induced oxidative damage and apoptosis in splenocytes of mice. Toxicol. Int. 21, 8-17.

15. Sarker, R.S.J., Ahsan, N., Hossain, K., Goush, P.K. and Akhand, A.A. 2012. Protective effects of water hyacinth (Eichornia crassipes) on sodium arsenite-mediated adverse effects in mice. Avicenna J. Med. Biotech. 4, 148-154.

16. Sayed, S., Ahsan, N., Kato, M., Ohgami, N., Rashid, A. and Akhand, A.A. 2015. Protective effects of phyllanthus emblica leaf extract on sodium arsenite-mediated adverse effects in mice. Nagoya J. Med. Sci. 77, 145-153.

17. Lee, K.W., Lee, H.J. and Lee, C.Y. 2002. Antioxidant activity of black tea vs. green tea. J. Nutri. 132, 785.

18. Beltz, L.A., Bayer, D.K., Moss, A.L. and Simet, I.M. 2006. Mechanisms of cancer prevention by green and black tea polyphenols. Anticancer Agents Med. Chem. 6, 389-406.

19. Khan, N. and Mukhtar, H. 2013. Tea and health: studies in humans. Curr. Pharm. Des. 19, 6141-6147.

20. Hossain, M.S. Nibir, Y.M., Zerin S. and Ahsan, N. 2014. Antibacterial activities of the methanolic extract of Bangladeshi black tea against various human pathogens. Dhaka Univ. J. Pharm. Sci. 13, 97-103.

21. Akhand, A.A., Kato, M., Suzuki, H., Miyata, T. and Nakashima, I. 1998. Level of $\mathrm{HgCl}_{2}$-mediated phosphorylation of intracellular proteins determines death of thymic T-lymphocytes with or without DNA fragmentation. J. Cell. Biochem. 71, 243-253.

22. Karim, M.R., Rahman, M., Islam, K., Mamun, A.A., Hossain, S., Hossain, E., Aziz, A., Yeasmin, F., Agarwal, S., Hossain, M.I., Saud, Z.A., Nikkon, F., Hossain, M., Mandal, A., Jenkins, R.O., Haris, P.I., Miyataka, H., Himeno, S. and Hossain, K. 2013. Increases in oxidized low-density lipoprotein and other inflammatory and adhesion molecules with a concomitant decrease in high-density lipoprotein in the individuals exposed to arsenic in Bangladesh. Toxicol. Sci. 135, 17-25.

23. Khan, M.M.H., Aklimunnessa, K., Ahsan, N., Kabir, M. and Mori, M. 2006. Case-control study of arsenicosis in some arsenic contaminated villages of Bangladesh. Sapporo Med. J. 75, 51-61. 
24. Stepnik, M., Stañczyk, M., Arkusz, J. and Lewiñska, D. 2005. Assessment of apoptosis in thymocytes and splenocytes from mice exposed to arsenate in drinking water: Cytotoxic effects of arsenate on the cells in vitro. J. Environ. Sci. Health A Tox Hazard Subst. Environ. Eng. 40, 369-384.

25. Lu, M., Levin, J., Sulpice, E., Sequeira-Le Grand, A., Alemany, M., Caen, J.P. and Han, Z.C. 1999. Effect of arsenic trioxide on viability, proliferation, and apoptosis in human megakaryocytic leukemia cell lines. Exp. Hematol. 27, 845-852.

26. Dua, T.K., Dewanjee, S., Gangopadhyay, M., Khanra, R., Zia-Ul-Haq, M. and De Feo, V. 2015. Ameliorative effect of water spinach, Ipomea aquatica (Convolvulaceae), against experimentally induced arsenic toxicity. J. Transl. Med. 13, 430. doi: 10.1186/s12967-015-0430-3.
27. Bhattacharya, U., Mukhopadhyay, S. and Giri, A.K. 2011. Comparative antimutagenic and anticancer activity of three fractions of black tea polyphenols thearubigins. Nutr. Cancer 63, 1122-1132.

28. Cabrera, C., Artacho, R. and Giménez, R. 2006. Beneficial effects of green tea - a review. J. Am. Coll. Nutr. 25, 79-99.

29. Messarah, M., Saoudi, M., Boumendjel, A. Kadeche, L., Boulakoud, M.S. and El Feki, A. 2013. Green tea extract alleviates arsenic-induced biochemical toxicity and lipid peroxidation in rats. Toxicol. Ind. Health. 29, 349-359.

30. Sinha, D., Roy, M., Dey, S., Siddiqi, M. and Bhattacharya, R.K. 2003. Modulation of arsenic induced cytotoxicity by tea. Asian Pac. J. Cancer Prev. 4, 233-237. 